\title{
Copacabana Non-Public: Toward a New Public Attitude
}

\author{
EDUARDO AQUINO \\ University of Manitoba
}

\begin{abstract}
More than a physicality, public space is a condition beyond an urban fragment or locality. Before it becomes a place, public space exists as a shared value. The devastation of the Amazon forest by multinational meat producers, the launch into space of a Tesla Roadster by Elon Musk, shootings in public schools, and the development of a new Trump tower in a big city somewhere in the world are just some examples of spaces being taken over by the relentless neoliberal advances into places that were once shared or not claimed at all, or simply considered "public." This process of takeover happens persistently in our cities, through ever-subtle or overstated methods by corporations and governments, by disfranchised groups, empowered tribes, or simply disguised by over-regulation. Starting from the premise that, in fact, "public space" as we know does not exist, this paper explores the notion of "non-public" as a critical foundation for a new reclamation of our cities. The paper plays the devil's advocate to counterpoint the frequent academic discourse that references public space as a normalized urban entity. Taking on a shifted direction Copacabana Non-public challenges the notion of what constitutes "public space" to change so many fixed assumptions. Instead of dancing around the subject, it exercises the consideration of the conditions that make public space in reality non-public-its constituencies and jurisdictions, its stakeholders and claimants, its crisis and promises. Taking Copacabana beach as a study case, Copacabana Non-public seeks to map out the real actors of public space to locate new strategies of engagement to transform its pseudo-public character, to identify policy and design strategies that reclaim urban spaces for more democratic citizenries.
\end{abstract}

\section{DOES PUBLIC SPACE EXIST?}

(Social) space is a (social) product [...] the space thus produced also serves as a tool of thought and of action [...] in addition to being a means of production it is also a means of control, and hence of domination, of power. ${ }^{1}$

In times where the political sphere seems extremely tenuous due to the instabilities of neoliberal politics, the consequent influence of capital to the urbanized world radically alters the idea of public. And for architects and urbanists the notion of public can no longer be reduced to the physicality of an urban space in simplistic manner, but needs to be revised and expanded, inviting concepts from political and economic practices, and as well lessons from philosophy and psychology. Once considered an urban characteristic resulted from the city progress on the 19th and 20th centuries, public space is under contention today as forms of domination and control challenge the more democratic modes of territorialisation, production, and distribution. Democracy in the second decade of the third millennium is under scrutiny, being questioned by the exposure of flawed systems of governance that substitute the social ideal to prevailing forms of capital concentration. Seeking a definition of public in times where fluxes of capitalist production are hostages of globalised forms political instability seems impractical. Notions of public can no longer be synthesized under the guise of academic formalisms. Even philosophy, as a tool of understanding, presents itself insufficient before the constant fluctuations observed in the radical transformation of our cities. More than a definition, this paper seeks to suspend conventional concepts of public space, problematizing the idea of public in favour of a new positioning toward the design and management of our cities.

\section{NON-PUBLIC}

The poverty of much urbanist thought can be reduced to a central fallacy: that the city, or Metropolis, expresses itself fully in its physical form, that as a finite concrete object alone it is amenable to analysis and intervention. The city, however, is not this, but rather a perpetually organizing field of forces in movement, each city a specific and unique combination of historical modalities in dynamic composition. ${ }^{2}$

Non-public explores this venue through the example of Copacabana Beach in Rio de Janeiro, Brazil, as one of the most reclaimed and intensely occupied urban places in a large metropolis. In Copacabana the scrutiny of what constitutes public is highly visible and tested in a daily basis. Exposed to a globalized audience through the reputation of seductive urban vibrancy, this urban beach circumscribes a type of space endowed with a flexible mechanism for negotiation between people and places, economies and cultures, architectures and the city, differentiating from more stable urban structures defined by buildings or infrastructure, and circumscribed by the limitations and rules of the "public." The city organization and enhancement of the urban experience can find more resources in the fluxes located on the beach. Fluidity, mobility, spontaneous feedback, and nonlinearity offer alternatives to the stability, predictability, and rationality of the city. Non-public identifies a territory characterized by a dynamic space, where urban agents are in constant 
transformation, generating a field of possibilities in the face of the stagnation of urban life. This renowned "public space" creates a permanent laboratory for the understanding of urban life and how the physicality of a "public space" is just a character among the complexities that form our cities. The urban beach shrinks and stretches its "public" qualities, suggesting alternatives to the organization, involvement and allocation of urban places. Each urban agent claims a section of public space, therefore transforming it in non-public, by defining it through a sense of privilege and dominance.

\section{CLAIMED "PUBLIC SPACE"?}

Richard Serra's Tilted Arc debacle (1981-89) marked a significant moment in the understanding of the complexities that entails a particular urban space and its constituencies-in this case the Foley Federal Plaza in Manhattan. The urban surface was occupied by an artwork that responded specifically to that site in terms of proportion, scale, and materiality, but even in doing so there were claims of otherwise: the sculpture disrupted the flow of traffic and cast a huge shade on the plaza, affecting on people's safety. A dispute erupted and at the end the sculpture was removed. Maybe there will never be unanimity among the affected over the purpose of this project on that specific site, but the Tilted Arc serves very well to point out the multifaceted aspects that surface when claiming an urban space that is considered "public." With the Tilted Arch there is only one constituency that was victorious in the process: the ones that were against it.

In any situation where a fragment of urban space is claimed by a group or individual, by an institution, corporate or governmental, it exposes all the agencies involved: either the ones who support it, the indifferent, or the ones who are against it. The truth is that every single urban territory has already been claimed, and if "public space" is "claimed" by a minority or institution wouldn't it cease to exist as "public"? On the other side, architects often refer to "public space" as the physicality, the material and formal aspects of an urban precinct. However, the only aspects that are truly public are not the physical ones, but exactly the political, economic, and psychological modes of relation that take place in the city. If "public space" has been historically defined by its own critique, based mostly on its formal aspects, it is necessary to revise some notions of "public" in order to reequip architects and urban designers to the challenging task of transforming our cities into better environments of conviviality and energy flows.

NOT PHYSICAL BUT SOCIAL, POLITICAL, ECONOMIC

For Henri Lefebvre social space is a social product, hence a tool of thought and action. Space, therefore, does not manifest itself solely as a physical entity. For Lefebvre urban space is formed by social relationships: complexity and flows, social constructions affecting social practices and perceptions, making the social production of urban space fundamental to the reproduction in capitalist society. This de-materialization of the physical through the emphasis on human relationships suggests a concept of public as a debasing of modernism. In articulating his mantra "the right to the city" Lefebvre states that "is far more than the individual liberty to access urban resources: it is a right to change ourselves by changing the city." He continues: "It is, moreover, a common rather than an individual right since this transformation inevitably depends upon the exercise of a collective power to reshape the processes of urbanization. The freedom to make and remake our cities and ourselves is, I want to argue, one of the most precious yet most neglected of our human rights. ${ }^{3}$ By placing the right to the city as the foundation of collective power and essentially as a common right, Lefebvre claims that the public is defined by a collective impetus toward the urban space. Jürgen Habermas also expands the idea of the public towards the representational space: not public space but public sphere. In this case public sphere is circumscribed by any condition that creates gathering: reading clubs, newspapers, masonic lodges, coffeehouses, etc. We can then even consider social media as part of this conglomerate of public infrastructures that bring more than a physicality, but ideas and individuals together, or the "informational right to the city," as Joe Shaw and Mark Graham propose. ${ }^{4}$

Both Lefebvre's "right to the city" or Habermas's "public sphere" collide against the very nature of so-called "public space": no longer in the public domain these once collective infrastructures become increasingly more privatized by the forces of capitalist neoliberal schemes, either by governments or corporations, therefore deceptive in nature, once considered "free institutions" reflected in the city. For Habermas, the decay of the public sphere is proportional to the growth of mass media. Physical urban spaces (e.g. Times Square) are invaded by corporate capitalism and mass consumption, generating passivity instead of activism. What becomes evident is that more than "public space" it is public value that raises as an authentic force. Public value is imbedded already in everyone's understanding, inherent to their code of conduct. While physical space is under the evaluation and dispute by different constituencies, public value is a currency common and respected by all. Everybody knows, accepts and respects the red traffic light; nobody confronts or disputes its value. Is there perhaps a new strategy where the technicians of the city could reevaluate the nature of urban spaces and translate them into authentic public value? Is there any hope for the so-called "public spaces" to be transformed into territory of authentic democratic inhabitation, above the deceptive infrastructuring of globalized neoliberal control? There is always a predominant constituency above other constituencies, like the workers of the Jacob Javits Federal Building were superior to other citizenries, especially the art community, therefore successful with the removal of Serra's Tilted Arc. "Public space" as it is, is overregulated, monetized, pre-claimed, and its own rhetoric developed carefully to appease citizenships through forms of control. 


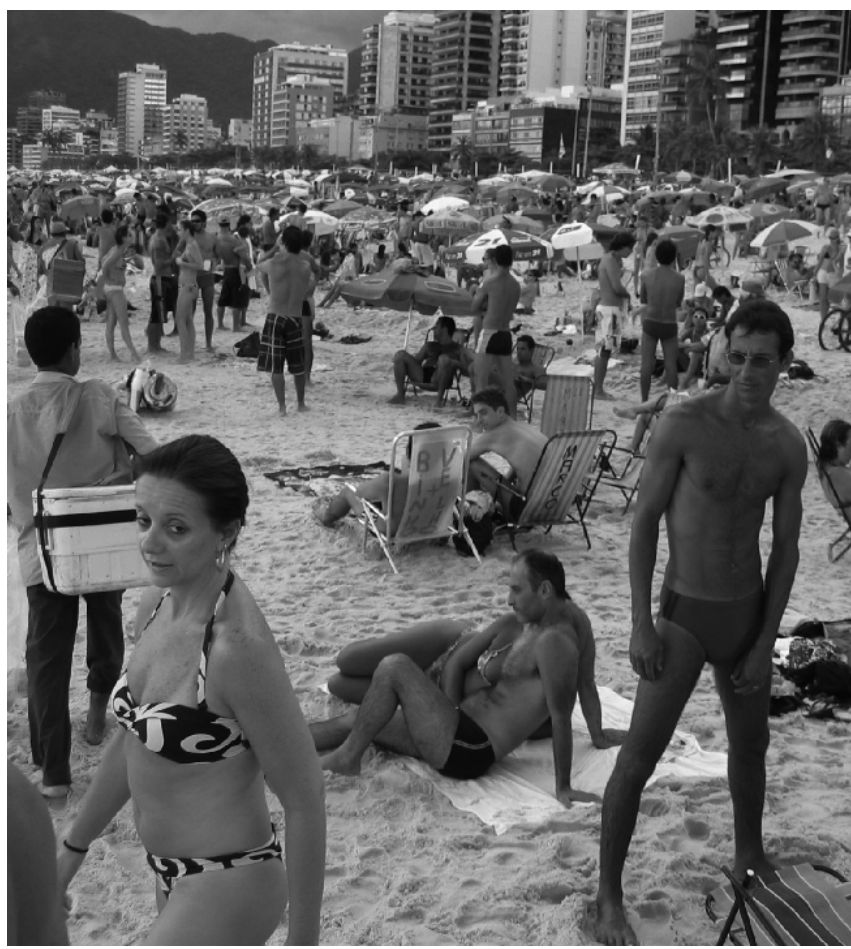

Figure 1: Ipanema Beach and its actors, adjacent to Copacabana Beach. Photo by Eduardo Aquino.

Consequently, tribes, regulations, governments, corporations, and even nature have an imposed, unbalanced power over the true value of public for most of the time. Habermas blames mass media as one of the causes for the dismissal of public space, making the consumer passive. It is this exacerbation of the individual over the collective what resulted on the rise of the politics of identity, reaching a climax, turning the urban space from a place of shared value into a site for self-interest and contestation, instead of recovering the collective sense through a public-minded consensus. As a more rigorous, critical, in-depth reevaluation of public space leads to its own contradiction-non-public-a new scrutiny of political and economic philosophies could lead to renewed, authentic strategies for other kinds of public scenarios.

\section{COPACABANA PUBLIC OR NON-PUBLIC?}

Copacabana is more than a neighborhood. It is the limit between the city and the stronghold. Copacabana navigates between the sensitive and the externally visible, offered by shapes, colors, architecture, traffic, and people, and, on the other hand, spaces reduced to the invisibility of daily life in which thousands of people submerge, anonymous faces stamped by an unknown life. ${ }^{5}$

Copacabana is a neighbourhood in the South of Rio de Janeiro. Its splendorous landscape, squeezed between the hills of the largest urban forest in the world and the Atlantic Ocean, presents itself as a perfect scenario for the enjoyment of nature in an urban setting, and the consequent human gathering to celebrate the moment. Copacabana's large population of 150,000 people-one of the densest neighbourhoods in Brazil-and its history and culture contribute to make this urban beach one of most popular in the world. It was here the cradle of Bossa Nova, and the site where samba thrives for most of the year, especially during Carnival. Anyone who has visited the beach of Copacabana might agree that it is one of the most intense and rich urban settings. With around 80 hotels Copacabana is one of the main destinations of tourists in Brazil, with Carnival and New Year's its most frequented celebrations. On weekends, the strip of sand is filled with locals and tourists. The boardwalk, in Portuguese mosaic stones, is famous for its wave pattern. Copacabana is filled with restaurants, bars, cafes, hotels, banks, churches, colleges, shops, theaters and art fairs on weekends. The commerce is quite diverse, with high-end stores mixed with others of more popular profile, besides the camelôs (street vendors). During the year Copacabana beach attracts multiple sports and cultural events. Often the New Year's party assembles 2 million people, but the biggest crowd was recorded in a mess performed by Pope Francis in 2013, which gathered 3.5 million people. The neighbourhood has 101 blocks, 79 streets, six avenues, and three favelas (Pavão-Pavãozinho, Cabritos and Ladeira dos Tabajaras) in an area of $7.84 \mathrm{~km}^{2}$.

The vast collection of physical and cultural apparatuses found in Copacabana generates a high degree of public life, provoked by the mingling between tourists and locals, the overlapping between the predominant middle class and the disenfranchised from the favelas, and the transient Rio population that come and go through the neighbourhood constantly throughout the day. This optimum infrastructure for urban living encouraged people to live together: the desire to be in a neighborhood with close contact with nature. Throughout its history this infrastructure was gradually implemented. Perhaps the two most significant examples is the introduction in 1920s of two tunnels linking Copacabana with the rest of the city, and Roberto Burle-Marx waterfront project of the 1970s. Both significantly enlarged the capacity and accommodated the urban precinct for more intense public engagement.

\section{COPACABANA AS A ZONE OF CONFLICT}

While Copacabana may appear to be an idyllic urban resort, its biggest social character is the massive gap between the rich and poor who inhabit the neighborhood. This detachment sharpens perceptions about the "other," as we can see in one of the most compelling sociological approaches to the beaches of the southern zone of Rio, by the American scholar and geographer James Freeman. ${ }^{6}$ Freeman argues that large Latin American cities are increasingly polarizing public space in an effort to overcome, for example, violence. But even though the tendency is to turn these spaces into dead urban spaces, the exceptionally vibrant Copacabana thrives in Rio de Janeiro. In the neighborhoods of the south of the city the 
residents spend much of their free time in the public domain: on the streets, in bars, and on the beach. Neighbors, friends and co-workers go from the inside out toward an intense social life. It is not surprising that $60 \%$ of Copacabana's population is above 60 years old. For Freeman this idyllic surface fed by the beach is a social space conflicted by racial and class divisions. Even though this society "Iubricates" the commercial zones, it promotes democracy and solves its own problems of common interest. This process still allows the participation of all in a true political possibility. Freeman's observations confirm here the position of Fredric Jameson, who considered critical distance to be a typical habit of modern thought, now abolished in the new postmodern space. ${ }^{7}$ For Jameson, we are so submerged to the point where our bodies are now stripped of spatial coordinates and virtually, incapable of detachment. The distancing is necessary as far as the approach of the object is concerned. Freeman in his social critique ratifies Jameson's assertion by bringing his outsider look to the Brazilian beach.

Through an ethnographic study of a section of Copacabana and Ipanema beach, James Freeman argues that the public space of the city can act as a kind of public sphere, where everyday class politics and racial interaction may be representative of the larger political dimension, even in a very segregated city like Rio de Janeiro. But the beaches of Rio de Janeiro can confer a kind of marginal citizenship to its users. They do not necessarily form the idealized discursive democracy on the part of social theory, nor are they the classless, highly miscegenated spaces that the Brazilian elite loves to mystify, but they articulate territories of deep conflict, where the arrastão, ${ }^{8}$ for example, emerge as a tense climax of urban social reality. At first, if the personal space (of the elites) is respected and safe, the impression of "democracy" seems to be evident, but in the minimum rupture of this personalized space, the conflicting issues are revealed publicly, through harmless events, such as the offering of a drink by a street vendor, or an accidental hefty on the shoulder. On the contrary, these events demonstrate political inequality, the confrontation of classes in which the legitimacy of the social order is continually challenged and renegotiated, even by a simple glance or by police action, defying the myth of democracy through the appearance of public space. If for Freeman the beach is a territory of contestation, for Jameson the beach could be considered a territory where hope is still possible through collective activism.

\section{COPACABANA'S HOPE}

Change life! Change Society! These ideas lose completely their meaning without producing an appropriate space. A lesson to be learned from soviet constructivists from the 1920s and 30s, and of their failure, is that new social relations demand a new space, and vice-versa. ${ }^{9}$

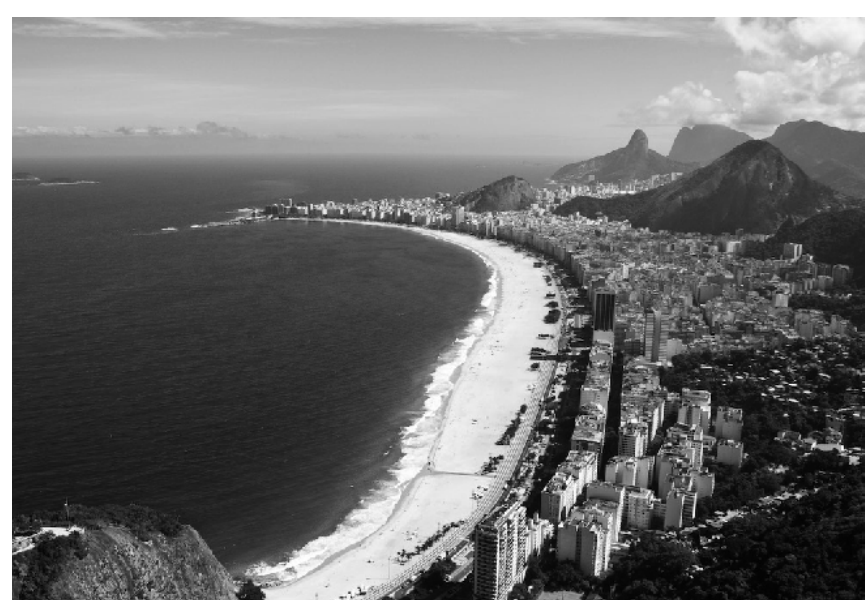

Figure 2: Copacabana Beach, Rio de janeiro, Attribution 2.0 Generic (CC BY 2.0) by Juniorpetjua.

Copacabana's expression of a public aspiration overwhelms the easily identified deficiencies, problems and conflicts on its sand, on its streets. Copacabana's energy for public daily reinvention makes this distinctive urban precinct of particular interest for urbanists and urban designers. Copacabana is a landscape in perpetual suspension, accommodating the most diverse fluxes of people and commodities, within the most paradoxical collision between nature and the built world. A political territory in constant negotiation, it defies all conventions or attempts in any fixed definition of "public space." A zone of permanent engagement, the social body finds in the pleasurescape all the contradictions presented by conflict that takes place under all forms of exchange: the apex of an ever-flowing relational ground-plan. Copacabana thrives in its own indeterminacy, offering the required flexibility for urban reinvention, making itself a laboratory for urban living. Social conflict coalesces with idleness, showing the possibility of coexistence of the individual and the collective within the urban field.

Habermas's optimism for the renewal of the public sphere indicates a process of political consciousness of the collective that surpassed the simplistic representation of democratic systems. Instead of having simple representation one should take real action to reclaim rights, assuming simultaneously responsibility over citizen's obligations. An engaged public sphere would be required not only for debate on matters related to public space, but for its real necessary transformations, either political, economic, social or physical. Only through what he calls "deliberative democracy" one can affect decision-making processes. It is in the confluence of a new collective political consciousness that a new city can emerge-no longer urban spaces submissive by the capricious favours of capitalism, but a new urban space where collective consciousness prevails. 


\section{TOWARD A NEW PUBLIC ATTITUDE}

In the contemporary city, we can no longer see public spaces with reference to a notion of urban, functional or semantic structure, as we did in the years of structuralism but, like the Greeks, we need to read civilised space as a topological, tactical order..$^{10}$
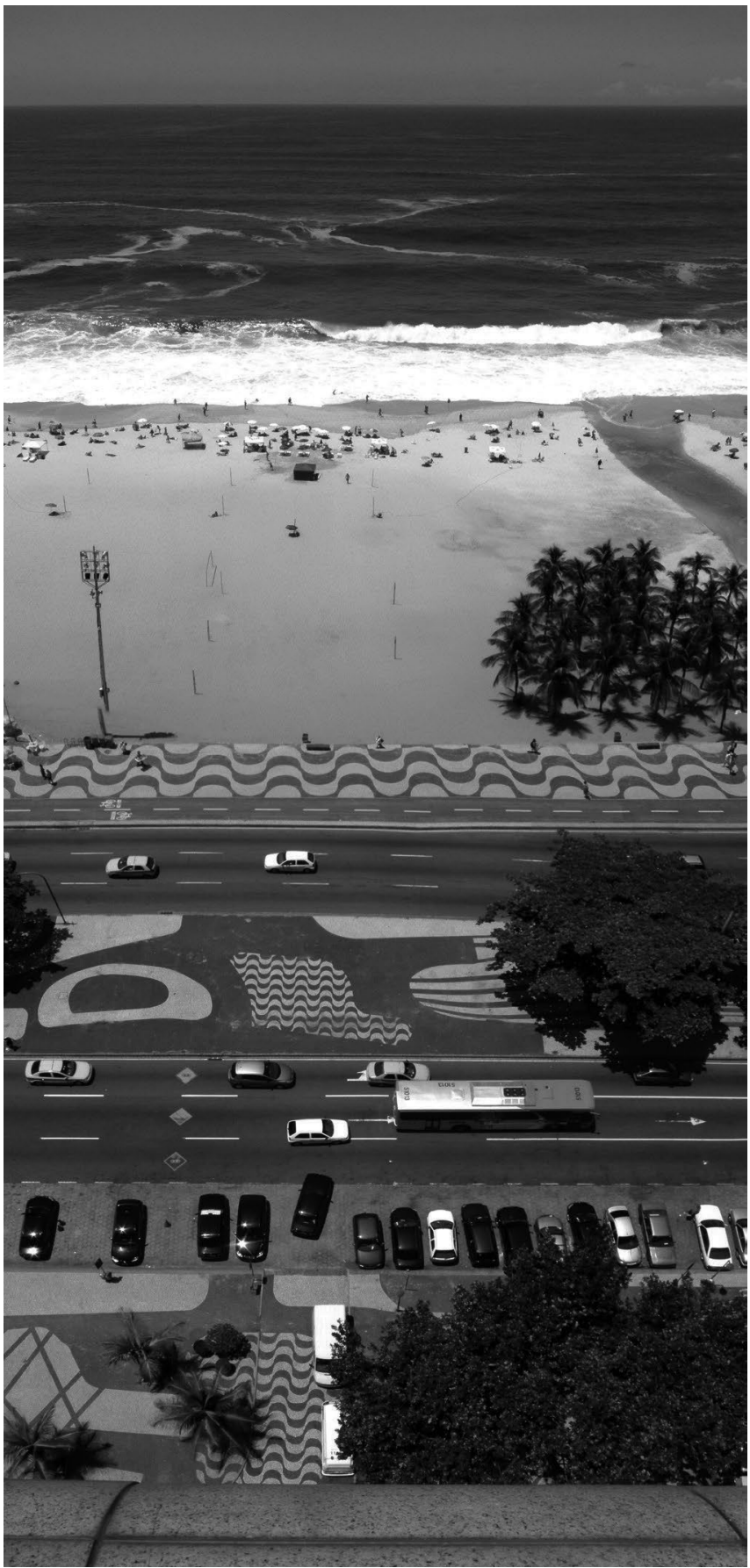

Figure 3: Copacabana beach section, showing the entire beach extension between the beachfront residential highrise and the ocean beyond. Photo by Eduardo Aquino.
Manuel de Solà-Morales, in his 2010 manifesto "The impossible project of public space" takes on the critique of design practices that reduce the nature of public space to a mere formal exercise, nailing in the head the fundamental problem of practices dealing with the city and the in-between. The contradiction here is the paradox of materializing something that is immaterial. We can recognize the non-public in designs that produce dead spaces through decorative means instead of programmatic moves, however design demands the conception of urban spaces that accommodate new forms of collective consciousness. Solà-Morales advocates the abandonment of old forms of materiality that sees the city as a canvas for poked objects of dubious civil validity. The critique straddles from urban design to landscape, from public art to architecture, claiming a new positioning regarding the creation of meaningful, effective, and truly public spaces in our cities. Solà-Morales reinforces:

The semantic debasement of the term "public space," which is indiscriminately used for any exercise in landfilling, transforming or prettifying vacant land. All too often, the category of "public space" is used without taking into account the requirement of real urban quality that the term entails. This urbanity is the quality of significant places of collective and political content in their very material form. "Material urbanity," the ability of urban material to express civic, aesthetic, functional and social meanings, is a basic concept when it comes to defining public space. ${ }^{11}$

What we have attempted here was not a redefinition of "public space" but to propose a new consideration of its concepts and practices. It has become clear that a revision of the way architects and urban designers address "public space" has to go through the scrutiny of a multifaceted approach toward the city beyond materiality. One cannot rest in the comfort of formal mannerisms and the consequent acceptance of its results. If the intent is to reclaim the city back from the forces that dictate the nature of our public experience in the city, then a new method of practice must be put in place. If one would question formalisms as a detriment to our urban spaces, the conception has to address the fundamental value of public. Public exists before "public space" is created, and it is in the root of public that we might find a new relevance for "public space" practice.

For Arjun Appadurai the globalizing condition that disregard the important of the local and the specific makes the individual the last active locus of this collection of generic landscapes. These individuals, the locus itself, safeguarded to their own imagination, act as a resistance toward the globalizing forces. ${ }^{12}$ The globalizing world forces the individual to remain in their subjective location, dreaming of the other, of an ideal life that takes place in another location, a process Appadurai refers to as imagined worlds. The beach presents itself as an ideal setting for the action referred here by Appadurai. The beach is located 
between being a landscape and an imagined world, simultaneously. At the same time mythical and provocative, the urban beach is a landscape that makes us conceive of a world made up of historically situated imaginations. The beach inserts us into the subjective imaginary in the middle of the objectified collective. The parity landscape/imagined world conceptualized by Appadurai clearly marks the way Copacabana, for example, imbues the life and mythologies of Rio de Janeiro. On the one hand it presents itself as an accessible public space at any time, the beach as a leisure zone, but it also occupies a unique place in the local, national and global imaginary.

The parity landscape/imagined world conceptualized by Appadurai clearly marks the way Copacabana, for example, imbues the life and mythologies of Rio de Janeiro. On the one hand it presents itself as an accessible public space at any time, the beach as a leisure zone, but it also occupies a unique place in the local, national and global imaginary.

Non-public reclaims the return of a post-urban possibility to reflect on other notions of "public," seizing upon the dynamics of the beach, looking back to the city, and through the example of Copacabana envisions a strategy to propose another positioning, another design, another public approach to space, reclaiming the urban precinct to a new constituency, to invest on the promise of a new role for urban design, architecture and urbanism as new forms of resistance. In this process the individual engages with the collective through a new agency, becoming active in the process of decision-making. Successful public spaces will be the ones that promote seamlessly this unanimity of true collective public value, without having to forcibly justify or impose any structure that worlds in genuine public spaces again.

\section{ENDNOTES}

1. Lefebvre, Henri. The Production of Space. Hoboken, NJ: WileyBlackwell, 1991, 26.

2. Kwinter, Sanford. and Daniela Fabricius. "Urbanism: An Archivist's Art?" in Mutations, edited by Rem Koolhaas, Stefano Boeri, Sanford Kwinter, Nadia Tazi, and Hans Urich Obrist. Barcelona and Bordeaux: Actar, 2001, 495.

3. Harvey, David. "The right to the city." New Left Review. New Left Review. II (53): $23-40$

4. Shaw, Joe, and Mark Graham. "An Informational Right to the City? Code, Content, Control, and the Urbanization of Information." Antipode, Volume 49, Issue 4, 907-927.

5. Coutinho, Wilson. Copacabana, cidade eterna: 100 anos de um mito. Rio de Janeiro: Relume Dumará, 2001, 9.

6. Freeman, James. "Great, good, and divided: the politics of public space in Rio de Janeiro." Journal of Urban Affairs, v. 30, n. 5. Hoboken, NJ: Wiley, 2008, 529-556.

7. Jameson, Fredric. Postmodernism, or, The Cultural Logic of Late Capitalism. London: Verso, 1991.

8. Arrastão in Portuguese refers to organized collective robbery, usually formed by groups of teenagers, who "sweep" the beach stealing anything that come in front of their eyes.

9. Lefebvre. The Production of Space, 59

10. Solà-Morales, Manuel. "The impossible project of public space." publicspace. org. https://www.publicspace.org/multimedia/-/post/the-impossible- projectorg. https://www.publicspace.org/multim
of-public-space (accessed June 31, 2018).

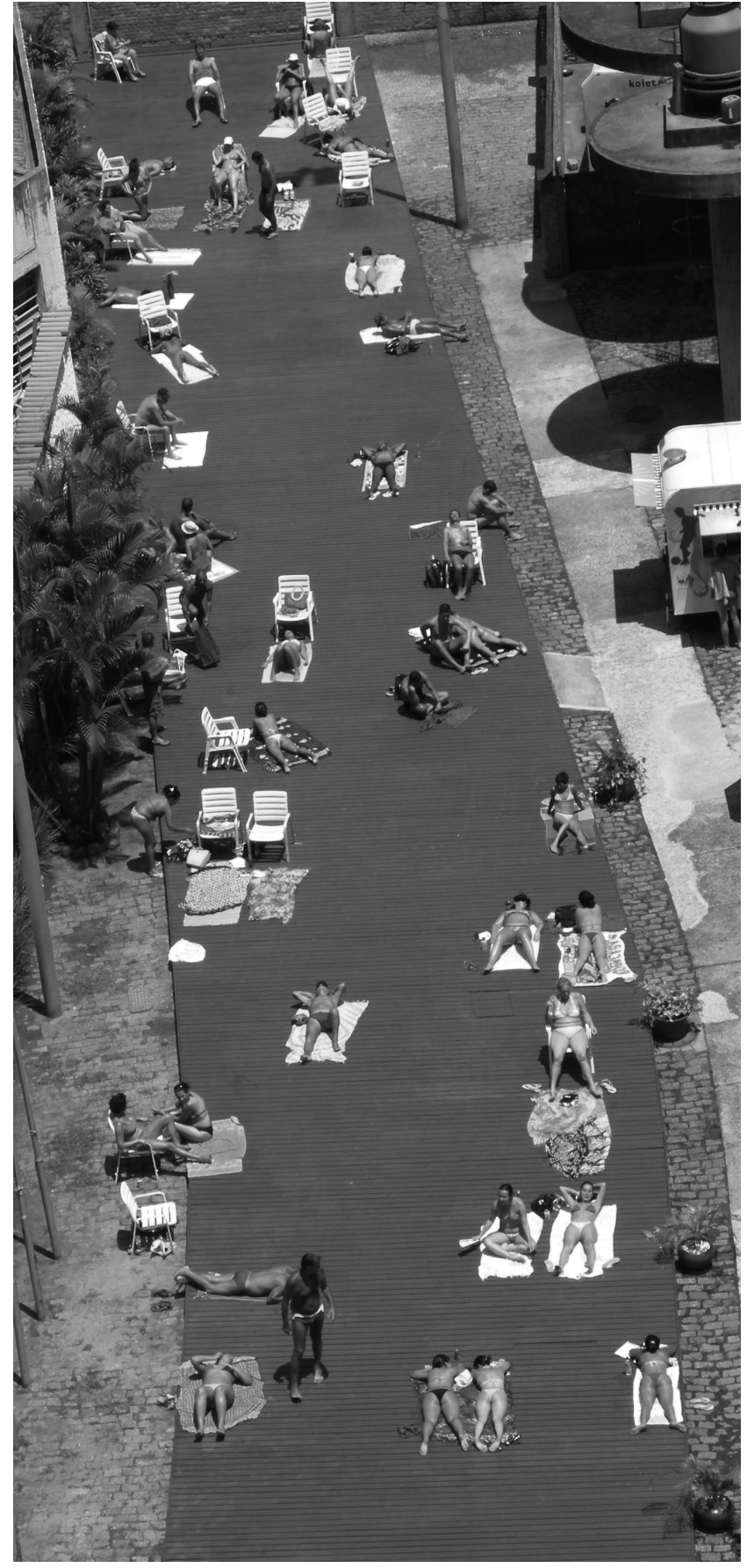

Figure 4: Beachscape at Lina Bo Bardi's SESC Pompéia, São Paulo, Brazil. Photo by Eduardo Aquino.

11. Arjun Appadurai. Modernity at Large: Cultural Dimensions of Globalization (Public Worlds, Vol. 1). Minneapolis: University of Minnesota Press, 1996,178 . 